\title{
東北地方太平洋沖地震津波来襲時の栈橋係留大型石炭船 の挙動再現について
}

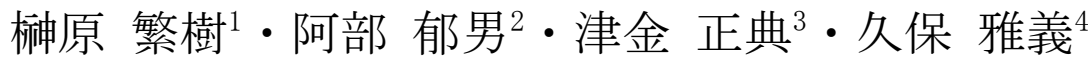

\section{Reproduction on Dynamic Behavior of a Moored Large Coal Carrier during the 2011 Tohoku Earthquake and Tsunami}

\author{
Shigeki SAKAKIBARA, Ikuo ABE, \\ Masanori TSUGANE and Masayoshi KUBO
}

\begin{abstract}
The 2011 Tohoku earthquake and tsunami at 14:46 JST on March 11, 2011 affected large areas of the eastern and northern part of Japan, and many sea disasters against vessels moored along terminal inside harbor basins occurred. We conducted surveys upon sea disasters of a VLCC at S-Port and an Aframax tanker at O-Port. There was also a severe disaster of large coal carrier at H-Port, which encountered a tsunami of tsunami wave height beyond 10 meters and damaged mooring equipment such as fenders and mooring lines, and unloader of coal, entirely. In this paper, we have also tried to reproduce the ship's behavior and analyze the mooring loads during the tsunami through a numerical simulation of tsunami and ship motion.
\end{abstract}

Keywords : Ship mooring, Tsunami, Ship motion, Mooring equipment, Unloader, Ocean engineering キーワード：港湾・倸留，津波，船体運動，係留施設，アンローダー、海洋工学

\section{1. 緒言}

著者らは東北地方太平洋沖地震津波来襲に伴い 被災した S 港原油栈橋で荷役・係留中であった VLCC を対象として、急激な押し波とこれに対抗するため に発動した本船推進力、また大きな船体運動による 係留索の巻き出し・切断および防舷材の過圧縮の発 生など、船長・乗組員の方々が遭遇した過酷かつ危 険な船舶の係留状況について津波および船体動摇シ ミュレーションを通して被災当時の定量的な把握を 試みた ${ }^{(1)}$ 。また $\mathrm{O}$ 港では係留避泊に成功したアフラ マックスタンカー (10 万トン級原油タンカー) の状 況把握や係留避泊を可能にした要因分析について、 同様なシミュレーションなどを用いて検討した ${ }^{(2)}$ 。
東北地方太平洋沿岸の他の港でも多数の大型船 の被苂実態が報告されているが(3)、本研究では、H 港で津波高さ $10 \mathrm{~m}$ 超の津波来襲に遭遇して係留・荷 役施設および本船に甚大な被害を受けた大型石炭船 の挙動につき、可能な限り入手できた被災状況を整 理すると共に、合わせて津波および船体動摇シミュ レーションを実施して被災当時の船体挙動や係留力 の再現を行い当該大型石炭船が遭遇した被災状況の 定量的な把握を試みる。

\section{2. 津波来襲時の大型石炭船の係留状況}

\section{1 対象港湾およびバース}

対象港湾は、外郭施設として北防波護岸・北防波 堤および南防波護岸・南防波堤が配置され、港口は

\section{正会員 東海大学 海洋学部 \\ 非会員 常葉大学 社会環境学部 \\ 正会員 前東海大学 海洋学部 \\ 正会員 神戸大学名誉教授}

( $\bar{\top} 424-8610$

( ₹417-0801

( ₹424-8610

( 产658-0022
静岡県静岡市清水区折戸 3-20-1)

静岡県富士市大淵 325)

静岡県静岡市清水区折戸 3-20-1)

兵庫県神戸市深江南町 5-1-1) 
南東方向に開いている。対象バースのある揚炭栈橋 には 2 隻の大型石炭船が同時係留可能であり、栈橋 の法線はほぼ南北方向（方位 348 度）である。そし て対象バースは当該栈橋の南側バースであった。港 内は当該栈橋前面およびターニングベイスンを含み 水深- $14 \mathrm{~m}$ 以上を確保しているが、南防波護岸の港内 側にある揚油バース前面では水深 $-5 \sim-9 m$ と浅くな っている。また北および南防波護岸の港外側は水深 $-10 \mathrm{~m}$ 以下の浅い海岸線となっている。

\section{2 対象船舶の諸元および係留図}

Table 1 および Fig. 1 に津波来襲時の当該大型石 炭船の船体諸元および係留図を示すが、左舷付けで あった。 とし、 $\mathrm{kx}, \mathrm{ky}, \mathrm{kz}$ は各軸周りの船体の慣動半径であ る。Fig. 1 に示寸ように当該石炭船は $\phi 65 \mathrm{~mm}$ ナイロ ンロープ 16 本および栈橋標準ブロック (幅 $28 \mathrm{~m}$ ) ごと に設置された防舷材 6 基で係留される状況であった。 係留索の初期張力は当該石炭船の一般的な值として 一律に $49 \mathrm{kN}$ (5ton) と設定した。Table 2 に係留条件 詳細をまとめるが、Sway，Surge の固有周期も合わ せて追記した。Fig. 2 には係留索の特性曲線を示す。 一方防舷材はFig. 3 にバネ特性を示すが、反力漸増 型の空気式 $\phi 2000 \mathrm{~mm}$ (直径) $\times 2000 \mathrm{mmH}$ (高さ) で

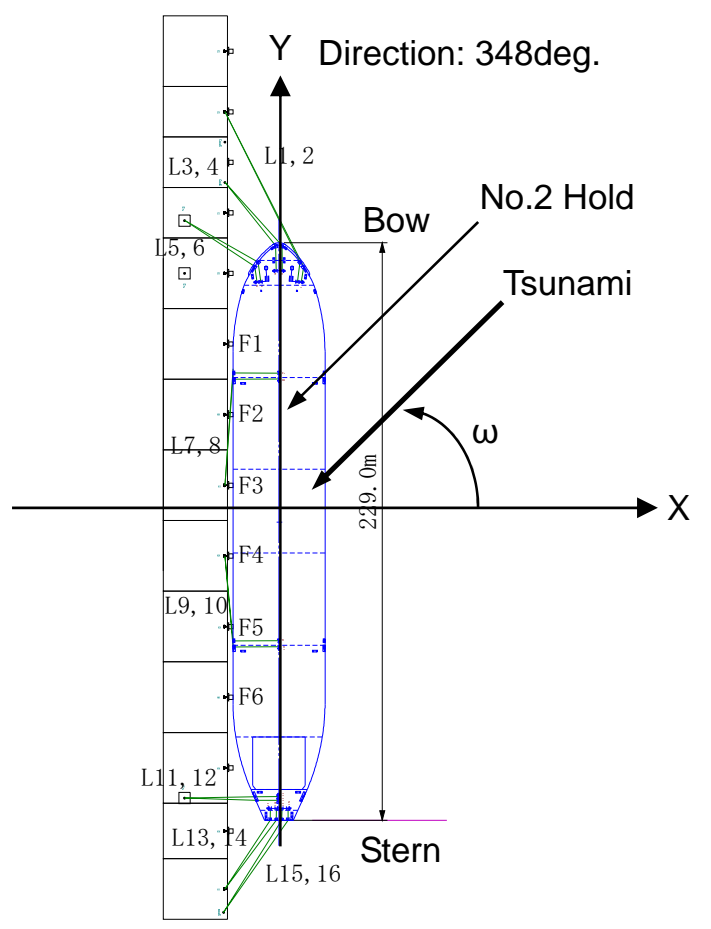

Fig.1 Mooring arrangement of the coal carrier
ある。規定の圧縮率は高さの $65 \%$ であるが、 $85 \%$ 圧 縮率（圧縮量 $1.7 \mathrm{~m}$ ）の過圧縮時までを設定した。

座標系は船体重心位置を原点にとった空間固定 座標系として船体座標系を設定し、X 軸正方向が右 舷、Y 軸正方向が船首および Z 軸正方向が鉛直上向 きの右手系としている。

Table 1 Ship dimensions

\begin{tabular}{|l|c|}
\hline Ship type & Coal carrier \\
\hline DWT & 77,739 \\
\hline Loa $(m)$ & 229.0 \\
\hline Lpp $(m)$ & 218.0 \\
\hline$B(m)$ & 36.5 \\
\hline $\mathrm{D}(\mathrm{m})$ & 18.5 \\
\hline$d_{m}(m)$ & 12.1 \\
\hline $\operatorname{Disp}($ ton $)$ & 83,197 \\
\hline$G M(m)$ & 4.65 \\
\hline $\mathrm{KG}(\mathrm{m})$ & 10.58 \\
\hline $\mathrm{kx}(\mathrm{m})$ & 69.76 \\
\hline $\mathrm{ky}(\mathrm{m})$ & 11.97 \\
\hline $\mathrm{kz}(\mathrm{m})$ & 69.76 \\
\hline
\end{tabular}

Table 2 Mooring condition

\begin{tabular}{|l|l|c|}
\hline \multicolumn{2}{|l|}{ Ship type } & Coal carrier \\
\hline \hline \multirow{4}{*}{ Lines } & Type & Nylon \\
\cline { 2 - 3 } & dia(mm) & 65 \\
\cline { 2 - 3 } & number & 16 \\
\cline { 2 - 3 } & $\begin{array}{l}\text { Pre- } \\
\text { tension(kN) }\end{array}$ & 49 \\
\cline { 2 - 3 } & SWL(kN) & 241 \\
\cline { 2 - 3 } & BL(kN) & 917 \\
\hline \multirow{4}{*}{ Fenders } & Type & $\begin{array}{c}\text { Pneumatic } \\
\text { 2000H x 2000D }\end{array}$ \\
\cline { 2 - 3 } & Interval(m) & 28 \\
\cline { 2 - 3 } & number & 6 \\
\hline \multirow{2}{*}{$\begin{array}{l}\text { Natural } \\
\text { period(s) }\end{array}$} & Sway & 151 \\
\cline { 2 - 3 } Jetty type & Surge & 187 \\
\hline Water depth(m) & Pier \\
\hline \multicolumn{2}{|l|}{} & 14 \\
\hline
\end{tabular}

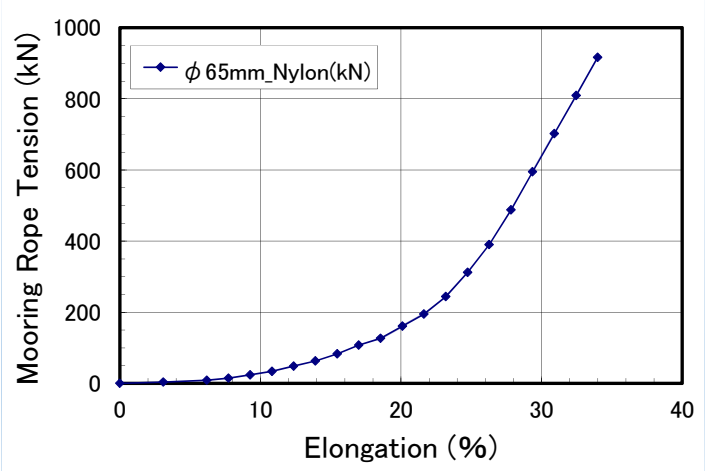

Fig.2 Mooring line property of the coal carrier 


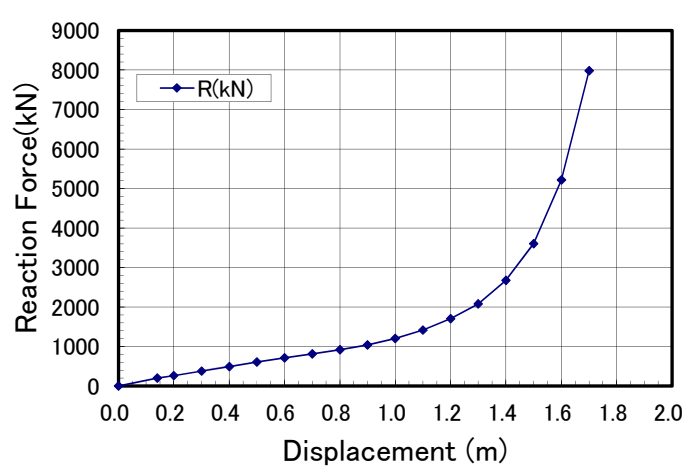

Fig.3 Fender reaction force property of the coal carrier

\section{3 ヒアリング調査から把握される船体挙動、 海面状態および被災状況}

被災が甚大であったことから津波来襲当時の船 体挙動や海面状態の状況を詳細に把握することは困 難であったが、バースマスターへのヒアリングおよ び被災後の本船や係留施設などの状況をできる限り 収集し、把握できた事項・できなかった事項を Table 3 のように整理した。Table 3 から被苂当時の本船の 状況を要約すると次のようである。

本船は揚げ荷役を開始直後でほぼ満載状態で地 震および津波の来襲を受けた。揚炭機（アンローダ 一)はNo. 2 ホールドに挿入されて当初荷役を行って いたが、地震によりアンローダ先端部はホールド内 に残された。津波高さは痕跡高さから $10 \mathrm{~m}$ 超で、防 波堤や護岸を越える越流が生じた。津波第 1 波来襲 時に大きなPitchやRoll が生じたと報告されている。 また栈橋設置の防舷材 6 基が破損して、当該石炭船 が栈橋に接触したと思われる栈橋損傷もみられた ${ }^{(4)}$ 合わせて係留索 16 本全数が破断または巻き出され た。これに伴い大きな船体動摇が生じ、本船はアン ローダ先端部を引きちぎり栈橋から流出した。そし て港内を漂流し、最終的には港内浅瀬部に座礁した。

Table 3 Summary of obtained information of sea disaster of the coal carrier

\begin{tabular}{|c|c|c|c|}
\hline \multicolumn{2}{|c|}{\begin{tabular}{|l|l|} 
No. & Item \\
\end{tabular}} & \multirow{2}{*}{\begin{tabular}{|l|}
\multicolumn{1}{|c|}{ Obtained data } \\
Ship dimensions(Loa, Lpp. B, d. W), Mooring \\
arrangement Cargo handling, 16:10 AIS \\
data. Grounding position, Ship motion at the \\
initial onset of tsunami
\end{tabular}} & \multirow{2}{*}{\begin{tabular}{|l|} 
not obtained data \\
AIS data, \\
Anchor usage, \\
Main engine activation
\end{tabular}} \\
\hline 1 & $\begin{array}{l}\text { Ship (Body, Anchor, } \\
\text { Main engine) }\end{array}$ & & \\
\hline 2 & Tsunami & \begin{tabular}{|l} 
Tsunmai profile during 14:46 16:46(7200s) \\
by simulation, Tsunami height over 10m, \\
Current over 10k't
\end{tabular} & $\begin{array}{l}\text { It is essential how to investigate the } \\
\text { simulation result. Several tsunami survay } \\
\text { reports were published. }\end{array}$ \\
\hline 3 & Fenders & Six fenders broken (over comp. $\rightarrow$ broken) & Which order were the fenders broken by ? \\
\hline 4 & Mooring lines & All lines pulled out/broken. & Which order were the lines broken by? \\
\hline 5 & Pier & $\begin{array}{l}\text { Fenders broken } \rightarrow \text { Top side concrete on the } \\
\text { pier damaged } \rightarrow \text { Piles of the pier safe }\end{array}$ & Spring constant of the pier? \\
\hline 6 & Unloaders & $\begin{array}{l}\text { Leader of one unloader remained in No.2 } \\
\text { hold by the earthquake } \rightarrow \text { Large ship motion } \\
\text { induced by tsunami } \rightarrow \text { The boom bended and } \\
\text { leader broken }\end{array}$ & $\begin{array}{l}\text { Weight of unloader: } 1100 \text { ton? } \\
\text { Spring constant of the boom? } \\
\text { Breaking load of the boom and leader? }\end{array}$ \\
\hline 7 & Tsunami wave forces & Elevation and currents in time series & Predominant wave direction? \\
\hline
\end{tabular}

\section{3. バース前面での津波計算と大型石炭船} に作用する外力の設定

\section{1 バース前面津波の水位変動および流速の 再現計算}

当該津波来襲時の大型石炭船の挙動再現に当た っては、対象バース前面における津波の水位変動と 流速データが必要となる。これに関しては東北地方 太平洋沖地震による津波浸水範囲を良好に再現でき る地震断層モデルが東北大学から提案されており、 それらの地震断層モデルをもとに津波の初期水位分 布を推定し、非線形長波理論（格子間隔 $50 \mathrm{~m}$ ）によ る津波シミュレーションを用いて当該栈橋周りの津 波の水位変動と流速を算出した ${ }^{(5)(6)}$ 。

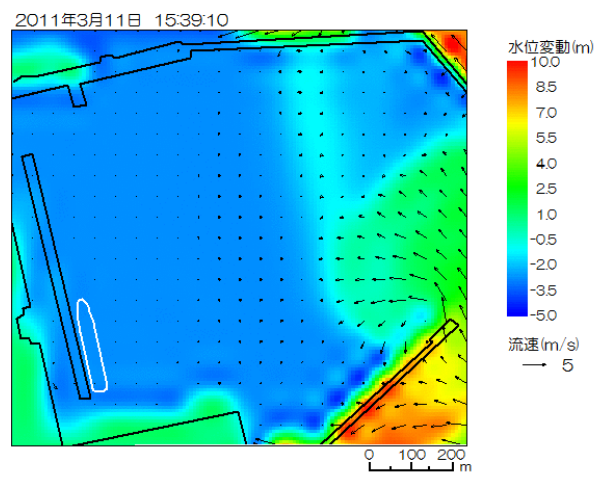

(a) At 15:39:10 (3190s)

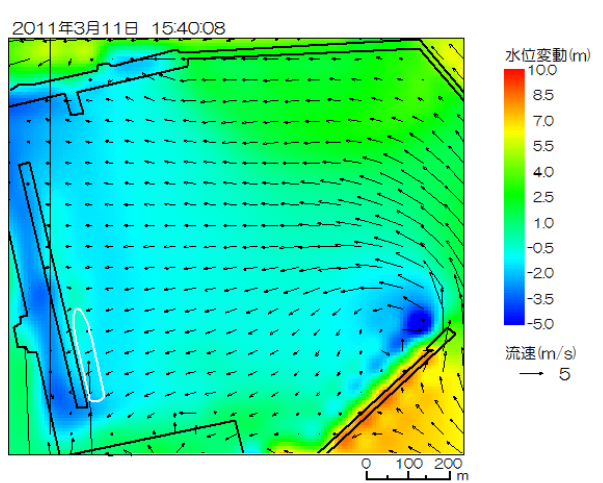

(b) At 15:40:08 (3248s)

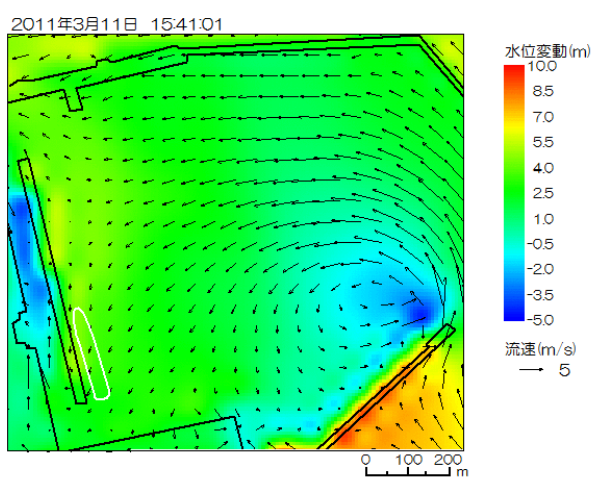

(c) At 15:41:01 (3301s) 


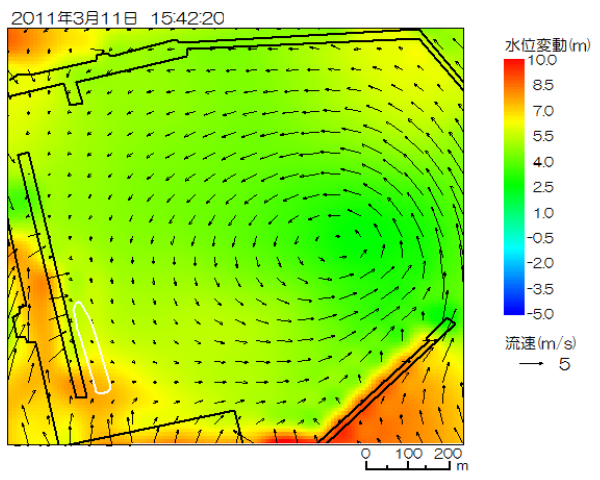

(d) At 15:42:20 (3380s)

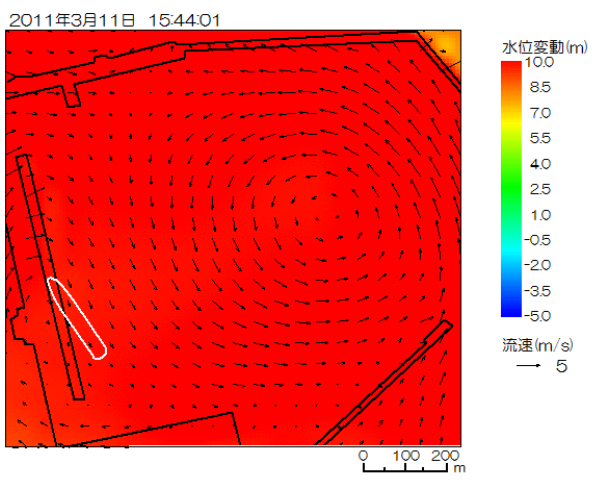

(e) At 15:44:01 (3481s)

Fig. 4 Numerical results of tsunami elevation and current around the coal carrier
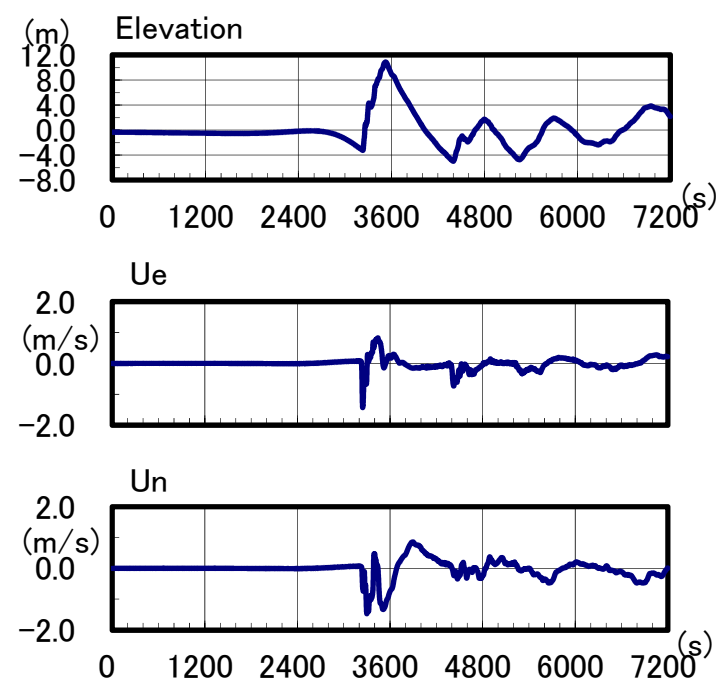

Fig. 5 Numerical results of tsunami profile for the moored coal carrier (14:46-16:46 on March 11)

対象栈橋周辺には港口からの津波来襲と合わせ て南防波護岸からの越波が来襲していたことがヒア リング調査などから把握されている。このことから 船体に作用する津波の水位変動や流速の設定に際し ては、Fig. 4 に示すように当該栈橋周りの防波堤を
含み概ね港内全域に渡る東西方向 1100m、南北方向 $1000 \mathrm{~m}$ 範囲の平面的かつ時系列的な流況を算出し確 認した。Fig. 4(a) は港口より押し波が来襲した船体 周りおよび港内の流況を示している（15 時 39 分 10 秒，3190s)。Fig.4(b) は押し波が栈橋前面の当該石 炭船に直撃したときの流況でほぼ右舷正横から津波 が来襲している様子がわかる（15 時 40 分 8 秒, 3248s)。Fig. 4(c) は港口から来襲した押し波が港内 を 1 周した状況 (15 時 41 分 1秒，3301s) で、Fig. 4(d) は南防波護岸からの越流が栈橋に来襲した状況であ る（15 時 42 分 20 秒, 3380s)。Fig. 4(e) は港内全域 が $10 \mathrm{~m}$ 超の津波高さとなり、港内中央で $10 \mathrm{kt}$ を超え る流速が生じている。また陸域にも越流が広い範囲 で来襲し、押し波来襲から約 5 分で港湾のほぼ全域 が津波高さ $10 \mathrm{~m}$ 超となっていたことがわかってきた。 また当該石炭船の栈橋周りでは、南東側の港口から 来襲する津波と南防波護岸・南防波堤からの越流が 陸側から来襲する複雑な流況になっていたこともわ かってきた。このため船体に作用する津波の水位変 動および流速の代表波形としては、船体中心付近で 算定された Fig. 5 に示す津波データを用いた。津波 の水位変動および流速データは 2 時間分のデータを 設定し、水位変動、東西および南北流速の最大・最 小值はそれぞれ+10.9m（押し波）、-5.0m（引き波）、 $+0.8 \mathrm{~m} / \mathrm{s}$ (東流)、 $-1.4 \mathrm{~m} / \mathrm{s}$ (西流) および+ $0.9 \mathrm{~m} / \mathrm{s}$ (北 流)、 $-1.5 \mathrm{~m} / \mathrm{s}$ (南流) となった。

\section{2 大型石炭船に作用する外力計算および 設定}

\section{2.1 波力}

当該石炭船に作用する津波波力を求めるに際し ては、従来のように卓越波向きを設定した線形波力 の重ね合わせによる波力算定方法を試みた ${ }^{(1)}$ (2)。し かしFig. 6 に示す流速のリサージュ図を作成したと ころ、卓越波向きの設定が困難なほど流向が全方向 に変動していることがわかった（港口からの津波来 襲だけでなく陸側からも栈橋に越流あり)。そこでモ リソン公式を用いる方法と船体周りの波形勾配から 算出する方法（船体長さに対して充分に津波の波長 が長いことを確認している）の 2 種類の波力算定方 法を、以下に示すように運動モード毎に適用した。

Sway, Surge, Yaw 波力は抗力および慣性力を考慮 するモリソン公式を用いて算定した（Yaw は抗力の み)。ここに抗力係数は水深影響と流れ向きから変化 させて与え、慣性力係数は 2.0 とした ${ }^{(7)}$ 。 


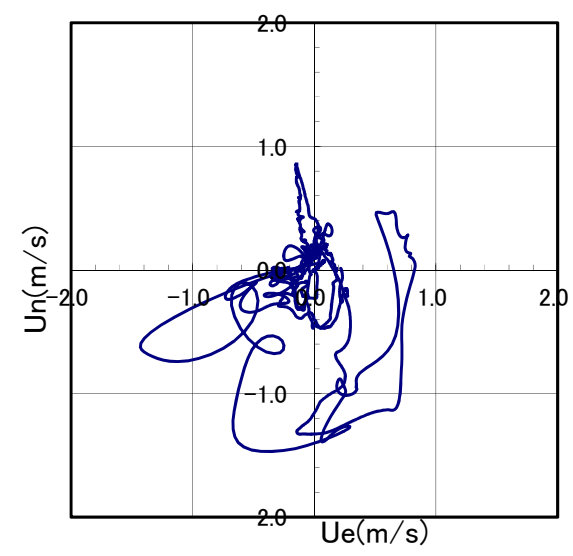

Fig. 6 Lissajous figure of the tsunami profile of Fig.5

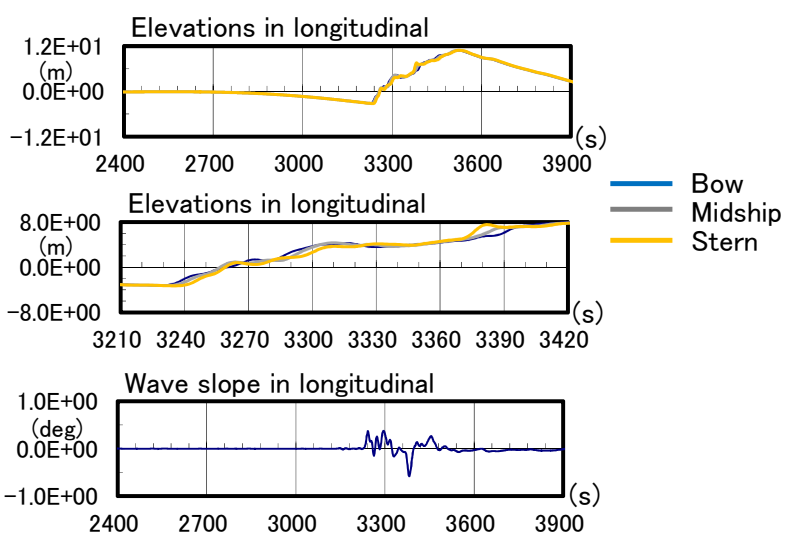

(a) in longitudinal(for pitch)
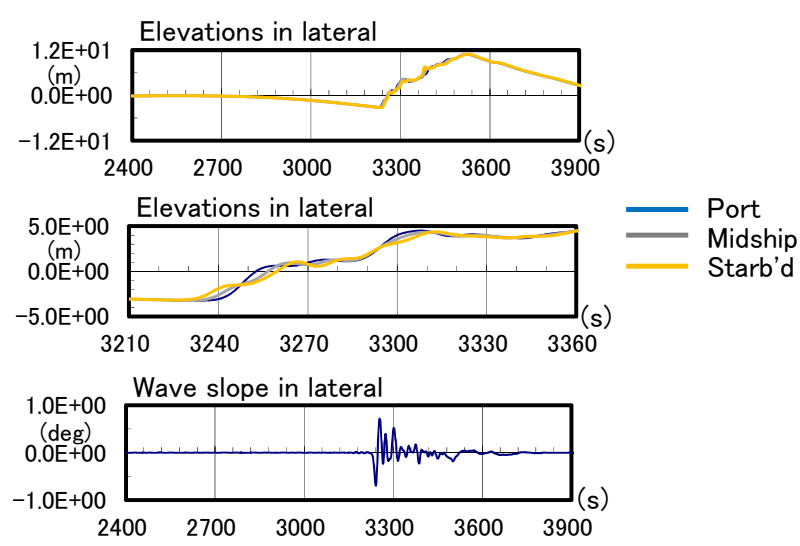

(b) in lateral (for roll)

Fig. 7 Wave slope calculated by surface elevations around the coal carrier

Heave 波力は船体重心位置付近の Fig. 5 に示寸水 位変動から与えた。また Pitch, Rol1 波力は Fig. 5 に示寸水位変動に対して、船首尾位置および船体左 右位置での水位変動から波形勾配 $\theta p=\theta p(t)$ および $\theta \mathrm{r}=\theta \mathrm{r}(\mathrm{t})$ を算出して、有効波傾斜係数を考慮して 算定した ${ }^{(8)}$ 。ここに有效波傾斜係数は 1.0 とした。 Fig. 7 (a) にはFig. 5 に示した船体中央付近での水位 変動に対して船首尾方向へそれぞれ $100 \mathrm{~m}$ 離れた位
置での水位変動、およびこれらから算出した船首尾 方向への波形勾配 (Pitch に相当)を示している。押 し波来襲時の計算点位置による違いを見やすくする ため、時刻 3210 s から 3420 s の変動を合わせて示し た。15 時 40 分 (3240s) 頃に船首側から水位上昇が 始まることから、プラス Pitch 角が生じている。ま た 15 時 42 分 20 秒 (3380s) 頃に南防波護岸からの越 流が栈橋に来襲した際には船尾側から水位上昇寸る ことからマイナス Pitch 角となっている。同様に Fig. 7 (b) にはFig. 5 に示した船体中央付近での水位 変動に対して左右方向へそれぞれ $50 \mathrm{~m}$ 離れた位置で の水位変動、およびこれらから算出した左右方向一 の波形勾配 (Ro11 に相当)を示寸。15 時 40 分 (3240s) 頃に右舷側から水位上昇が始まり、マイナス Rol1 角が生じていることがわかる。

\subsection{2 アンローダによる拘束カ}

上述のように、地震により当該石炭船のアンロー ダ先端部はホールド内に残された。ヒアリング調査 によると、津波第 1 波来襲時に大きな Pitch が生じ た際にはアンローダ先端部も船体動摇に合わせて上 下動をしていたとのことである。そこでアンローダ 内に残された石炭重量を船体に荷重として与えるこ とを考えたが、微小として無視した。一方 Sway, Surge に大きな船体動摇が生じてアンローダ先端部 がホールドハッチコーミングに接触するときおよび 引きちぎられる際に発生する船体拘束力については、 Fig. 8 に示寸ように区分的に線形バネ定数と接触変 位を設定することで、Sway，Surge および Yaw に考 慮した。ここにバネ定数などは栈橋バネと同等とし て以下のように設定した。

初期バネ定数 : Ku1 $=78,400 \mathrm{kN} / \mathrm{m}(8,000 \mathrm{tf} / \mathrm{m})$

2 次バネ定数 : Ku2 $=7,840 \mathrm{kN} / \mathrm{m}(800 \mathrm{kf} / \mathrm{m})$

一次変位 : Xss $=1 \mathrm{~m}$

二次変位 $: X \mathrm{sb}=2 \mathrm{~m}$

なお接触変位が Xsb を越えるとアンローダは倒壊す るものとして拘束力ゼロとした。また当該ホールド ハッチ開口部寸法は幅 $16.4 \mathrm{~m}$ ，長さ $27.3 \mathrm{~m}$ 、開口部中 央位置は船体重心から前方へ $38.83 \mathrm{~m}$ とした。合わせ てアンローダ先端部の断面形状は $3 \mathrm{~m}$ 角の正方形と し、初期位置はホールド内中央とした。

\subsection{3 着底カおよび船底摩擦力}

当該栈橋周辺の水深と Fig. 5 に示寸津波の水位変 動および当該石炭船の喫水状況から、押し波来襲前 


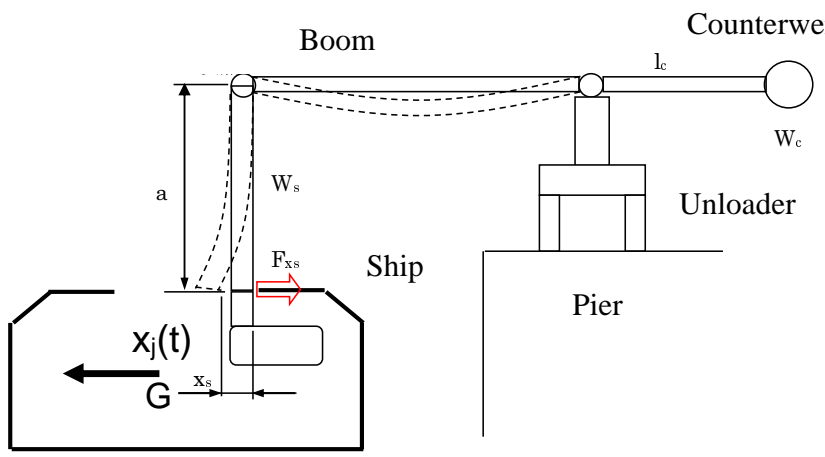

(a) Layout of unloader

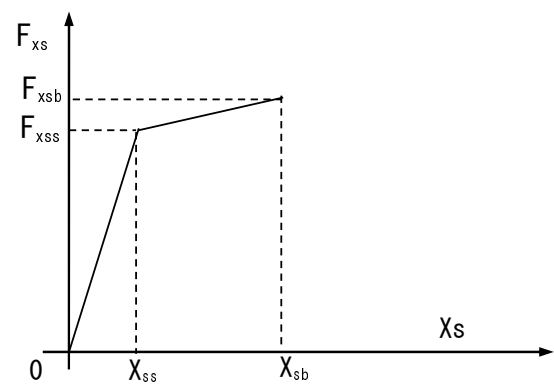

(b) Modeling of restricted force

Fig. 8 Modeling of unloader restricted force

の引き波時に本船船底が海底に着底する可能性が考 えられた。そこで着底力と船底摩擦力を考慮したモ デル化を流用した ${ }^{(9)}$ 。

\subsection{4 防舷材および栈橋からの反カ}

係留船に作用寸る防舷材反力は、規定の圧縮率以 内で防舷材を使用寸る場合では一般に防舷材単体の 反力特性を流用して船体への反力として与えていた。 しかし今回は大きな船体動摇により防舷材は破損し、 さらに栈橋と本船が接触して上部工が損傷する状況 となった。従来と異なる当該被災状況下での船体動 摇や係留力の再現シミュレーションを行うに際して、 防舷材と栈橋のバネ特性を合わせた新たなモデル化 を行った。

栈橋は防舷材取付け間隔に相当する $28 \mathrm{~m}$ ブロック 単位としてバネ定数を設定した。ここに類似の栈橋 詳細データを参照して、 $\phi 1400 \mathrm{~mm}$ の鋼管杭 20 本を ブロック当りに配置し、杭頭から海底面までの長さ $(18.7 \mathrm{~m})$ 、水平地盤反力係数などを設定した。そして 栈橋標準ブロック当りバネ定数を $\mathrm{Kp}=73,380 \mathrm{kN} / \mathrm{m}$ $(7,488 \mathrm{tf} / \mathrm{m})$ とした ${ }^{(10)}$ 。また防舷材が $85 \%$ 圧縮する までは防舷材と栈橋は直列バネとして同時に変形し (変位 $1.81 \mathrm{~m}$ まで)、その後に船体が栈橋に接触する 場合は栈橋バネのみにより反力が与えられるように モデル化した。Fig. 9 には防舷材単体、栈橋と合わ せた直列バネおよび栈橋のみのバネ特性を示す。

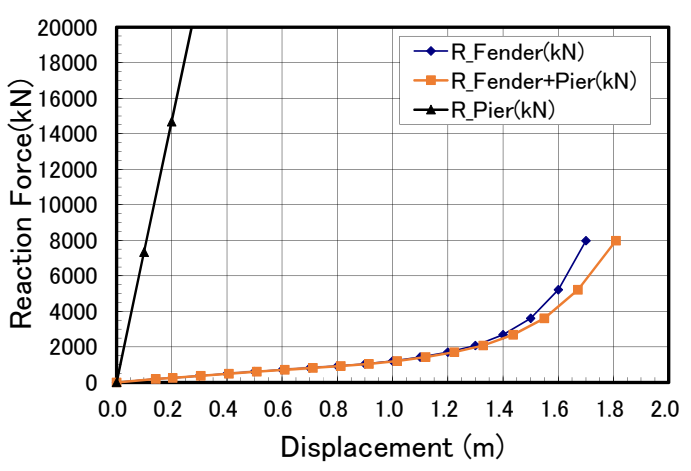

Fig.9 Fender and pier reaction force property of the coal carrier

\subsection{5 その他の外カ}

当該石炭船に作用するその他の外力としてはま ず風圧力が考えられるが、当時の風況としては微弱 であったことからゼロとした。また船体と防波堤間 に生じる側壁影響による吸引力や回頭モーメントの 影響は考えられるが今回考慮しなかった。

\section{4. 津波来襲時の大型石炭船の挙動再現 4.1 係留船舶の時系列解析}

当該地震津波来襲による大型石炭船の挙動再現 に際しては、式(1)，(2)の運動方程式を解くことで船 体運動量および係留力を算定するものとする。

$\sum_{j=1}^{6}\left\{M_{i j}+m_{i j}(\infty)\right\} \cdot \ddot{x}_{j}(t)+\sum_{j=1}^{6} \int_{-\infty}^{t} \dot{x}_{j}(\tau) \cdot L_{i j}(t-\tau) d \tau+\sum_{j=1}^{6} D_{i j} \cdot \dot{x}_{j}(t)$

$+\sum_{j=1}^{6} C_{i j} \cdot x_{j}(t)+G_{i}=F_{i}(t),(i=1,2, \ldots \ldots, 6)$

$F_{i}(t)=F_{e i}+F_{c e i}+F_{U}+F_{f r},(i=1,2, \ldots \ldots ., 6)$

ここに添字 $\mathrm{i}, \mathrm{j}$ は $\mathrm{j}$ モード運動による $\mathrm{i}$ モード運動 への寄与を表し、i, $j=1 〜 6$ は運動モードSway, Surge, Heave, Pitch, Ro11, Yaw である。 $x_{j}(t)$ は船体動摇 の変位または回転角、 $\mathrm{M}_{\mathrm{i} j}$, は船体の質量または慣性 モーメント、 $\mathrm{m}_{\mathrm{ij}}(\infty)$ は不変付加質量または不変付加 慣性モーメント、 $\mathrm{L}_{\mathrm{ij}}$ はメモリー影響関数、 $\mathrm{D}_{\mathrm{ij}}$ は粘 性減衰係数、 $\mathrm{C}_{\mathrm{ij}}$ は静的復原力係数、 $\mathrm{G}_{\mathrm{i}}$ は非線形係留 カベクトル、 $\mathrm{F}_{\mathrm{i}}$ は外力項である。外力項は津波波力

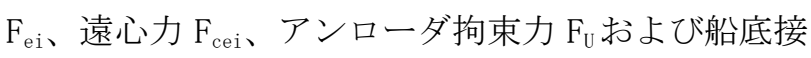
触による着底力・摩擦力 $\mathrm{F}_{\mathrm{fr}}$ により構成される。ま た防舷材および栈橋からの反力は非線形係留力ベク トルに加味した。粘性減衰力は Sway, Surge, Roll, Yaw に考慮し、合わせて係留索の張力算定において 係留索の巻き出しやウインチのブレーキ力を考慮し たモデルを用いた ${ }^{(1)}$ 。 


\section{2 船体挙動と係留力の再現}

以上の設定に基づき、式 (1)，(2)の運動方程式を 解くことで当該地震津波来襲時の石炭船の船体運動 や係留力を算定した。ここにFig. 5 に示寸水位変動 および流速において、地震発生後約 40 分頃 (2400s) から急激な引き波、引き続き押し波が来襲し流速変 化も生じている。このことから船体動摇シミュレー ションは 14 時 46 分の地震発生時から行っているが、 15 時 26 分 (2400s) から 15 時 51 分 (3900s) を表示す る。

\section{2.1 波力}

3.2.1 に示した津波波力算定方法により船体に作 用寸る津波波力を求めた。Fig. 10 に当該波力の時系 列計算結果を示す。

Heave に関しては津波の水位変動に一致した波力 となっている。Pitch 波力は時刻 15 時 42 分頃 (3382s) に船尾を持ち上げる急激な波力が発生して いる。これは陸岸からの越流が当該栈橋に来襲した 時刻に一致し、Fig. 7 (a) に示した船首尾方向波形勾 配に対応している。同様に Fig. 7 (b) に示した船体左 右方向波形勾配に対応して、Ro11 波力には押し波来 襲時の時刻 15 時 40 分頃 (3241s) に右舷側を持ち上げ る急激な波力が発生している。Sway, Surge 波力も

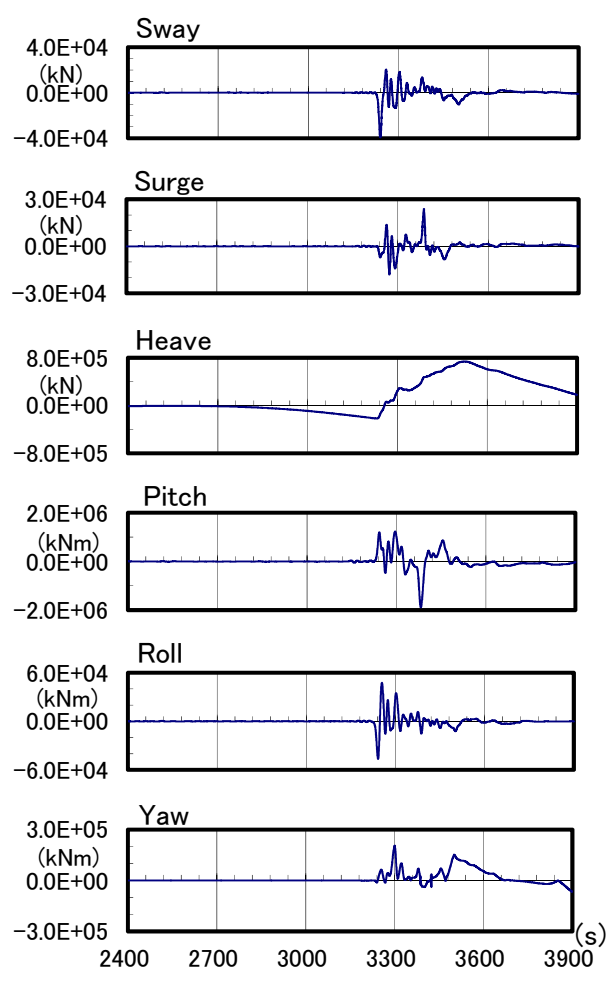

Fig. 10 Numerical results of the coal carrier's exciting forces during the tsunami
比較的顕著であるが、Sway には 15 時 40 分頃 (3240s) に船体を栈橋側へ押し付ける急激かつ大きな波力が 生じている。Yaw 波力は流速に対応した波力となっ ているが、概ね左舷回頭モーメントとなっているこ とがわかる。

\subsection{2 船体運動}

船体動摇量の時系列計算結果を Fig. 11 に示す。 Fig. 11 に示すように Sway, Surge, Heave および Yaw が顕著である。Heave に関しては津波の水位変動に 一致した動きであるが、水深 $14 \mathrm{~m}$ に対して喫水 $12.1 \mathrm{~m}$ であることから、3060s 頃から引き波最下点 $3232 \mathrm{~s}(-3.3 \mathrm{~m})$ まで船体は着底している。Sway は押し 波来襲 $(3240 \mathrm{~s}$ 頃)に-2m となり、その後は沖側への動 摇に伴いアンローダ拘束力により保持されるが、 3394.5s にアンローダーを引きちぎり沖側へ移動し ている。Surge は 押し波来襲により船尾側へ移動す るが 3300s 頃アンローダ拘束力により船首側へ移動 している。その後前後に移動するが、3394.5s にア ンローダーを引きちぎり、その後船首側へ移動して いる。上述の Sway, Surge からアンローダーはNo. 2 ホールドの左舷側船尾角で引きちぎられた可能性が 考えられる。

Pitch は押し波来襲時の当初は船首が持ち上げら れるが、3385s 頃の大きな船尾上昇は南防波堤を越

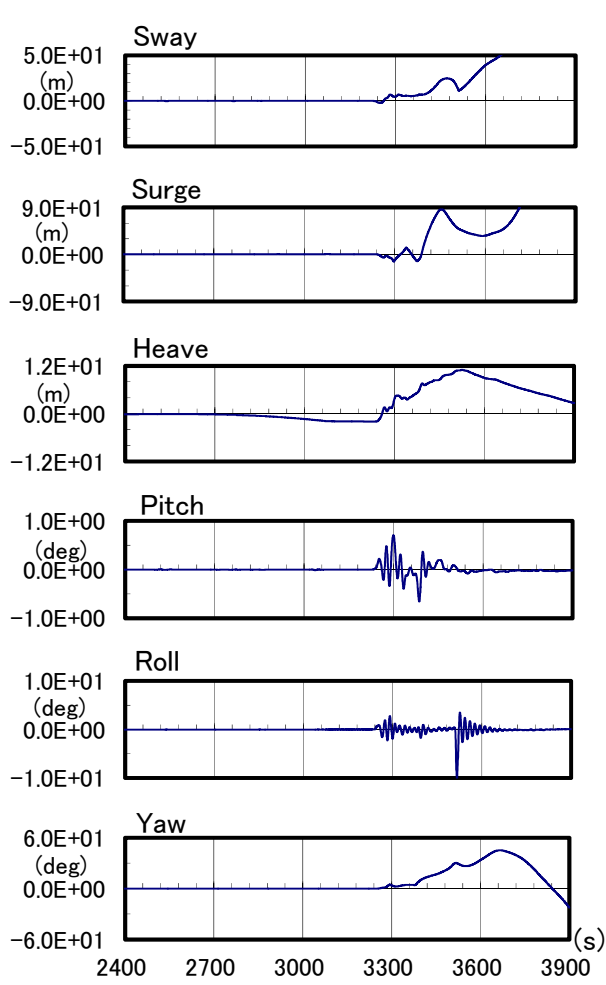

Fig. 11 Numerical results of moored coal carrier motions during the tsunami 
えてきた越流に起因寸る。Ro11 は押し波来襲から土 $2 \mathrm{deg}$ であるが、3517s 頃に-10deg 程の大きな動摇が 生じている。これは Yaw の大きな正回転により船首 側防舷材 (F1) に船体が接触し、合わせて水位上昇に より船体重心位置が防舷材取付けレベルの上側にな ったためマイナスの Roll（左舷摇れ）となった。Yaw は津波波力やアンローダによるYaw モーメントによ り正回転（左舷回頭）が生じ、その後は防舷材反力 （栈橋反力）や係留索の巻き出しが合わさり右舷回 頭となる大きな動摇が生じている。

\section{2.3 アンローダによる拘束カ}

アンローダーによる船体拘束力の時系列計算結 果をFig. 12 に示す。Fig. 12 に示すように Sway 方向 拘束力がマイナスのみ発生していることから、Sway 沖側への動摇により、アンローダ先端部はホールド ハッチコーミングの左舷側に接触していたことがわ かる。またこれに伴い Yawには左舷回頭モーメント を誘発している。Surge 方向拘束力は船首側および 船尾側へ変動しているが、アンローダ先端部はNo. 2 ホールドの左舷側船尾角で引きちぎられていること が Fig. 11 の船体動摇と合わせてみることで理解さ れる。

\subsection{4 着底力および船底摩撩力}

船体の着底による海底からの反力およびこれに 伴う摩擦力の時系列計算結果を Fig. 13 に示す。 Heave には引き波に合わせた船体着底力が反力とし て生じてことがわかる。一方 Sway， Surgeには押し 波来襲による摩擦力が生じている。摩擦力は当該動 摇速度の符号に対して逆向きに与えているため押し 波来襲時のマイナス Sway 動摇速度によりプラスの Sway 摩擦力が生じている。また Surge についても、 押し波来襲時のマイナス Surge 動摇速度によりプラ スの Surge 摩擦力が生じている。いずれも押し波に よる波力に対抗して作用寸るが、Fig. 10 の津波波力 に較べれば小さく船体動摇を抑制するほどではない。

\subsection{5 係留力}

\section{(1) 係留索張力}

Fig. 14(a)，(b)に係留索 L1 (head 1ine), L3 (head line), L7 (Forward spring line), L10 (Aft spring line), L11 (Aft breast line), L16 (stern line)の 張力および索長さの時系列計算結果を示す。

ヒアリング調査を参照して、係留索 L3，4，8，9， 13，14 は索長が短いことから、船体の大きな動摇発 生初期に切断したものとした。津波第 1 波が到達す る時刻 15 時 40 分 (3240s) 頃から、大きな船体動摇の 誘発に伴い、ウインチブレーキ力を超える張力が各

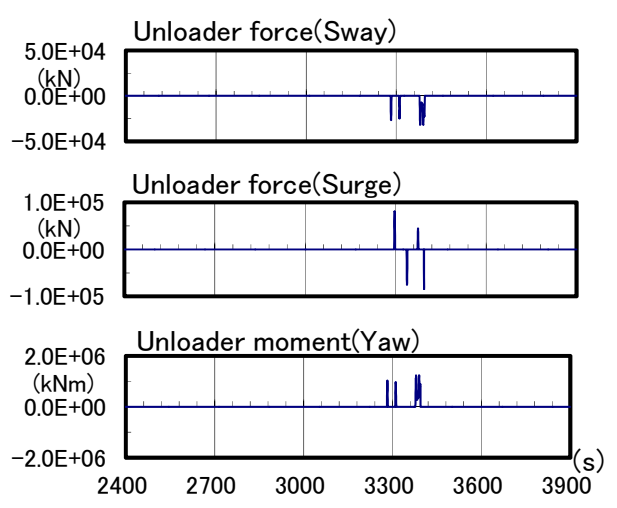

Fig. 12 Numerical results of unloader restricted forces of moored coal carrier during the tsunami

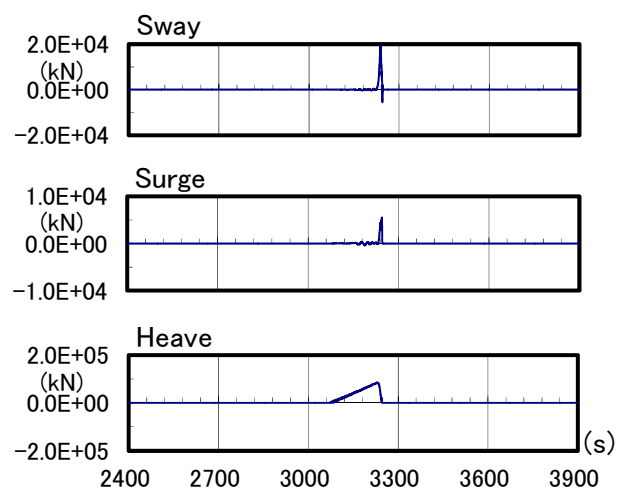

Fig. 13 Numerical results of grounding forces of coal carrier during the tsunami

索で生じ、係留索が漸次巻き出されている様子がわ かる。索長さは $200 \mathrm{~m}$ を基準としたが、係留索 L1, 7, 10，11，16 などでは 15 時 51 分 (3900s)までに全長 さが巻き出されて張力ゼロとなっている。係留索 L3 の場合、索長さを短く設定しているためにこれを超 えると張力ゼロとなり、索が破断したことを表して いる。

\section{(2) 防舷材反力}

Fig. 15 に防舷材反力の時系列計算結果を示寸。 Fig. 15 (b) には押し波来襲時の防舷材の状況（反力 $8000 \mathrm{kN}$ で破損）や栈橋との接触状況を見やすくする ため、時刻 3210s から 3420s の反力時系列結果を合 わせて示した。津波第 1 波が到達する時刻 15 時 40 分 $(3240$ s) までは、船体は防舷材に密着して全ての防 舷材に反力が生じ、係留索の初期張力と防舷材の反 カがバランスし緩やかな緊張係留が確保されている。 その後の津波第 1 波来襲による Sway, Rol1 および Yaw の船体運動に対応して反力が生じ、3242s までに 6 基全ての防舷材に $85 \%$ 圧縮率に至る変形が生じ、 3244s には13000 15000kNに及ぶ反力が発生してい る（栈橋のみバネによる）。Fig. 16 に防舷材反力と 


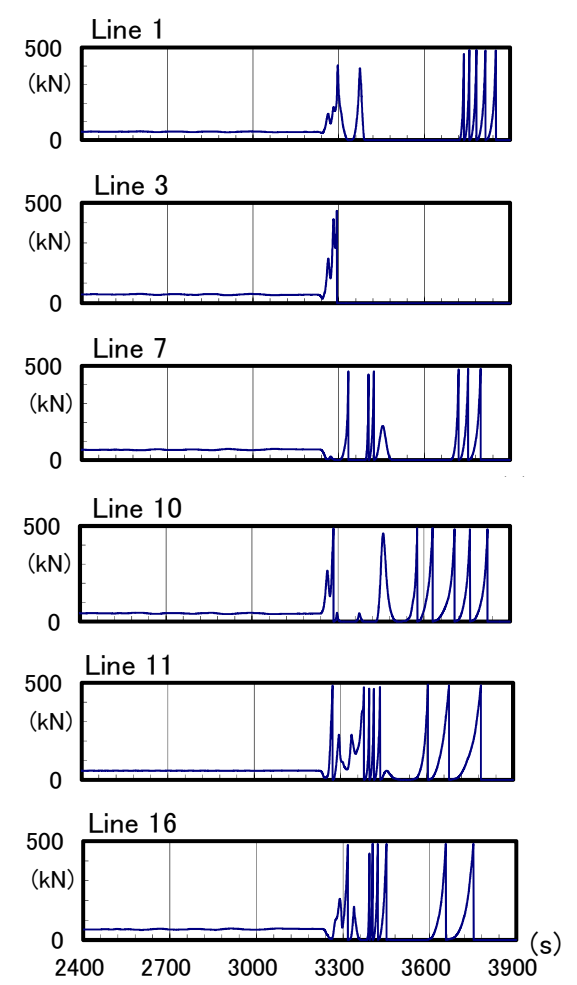

(a) Line tension
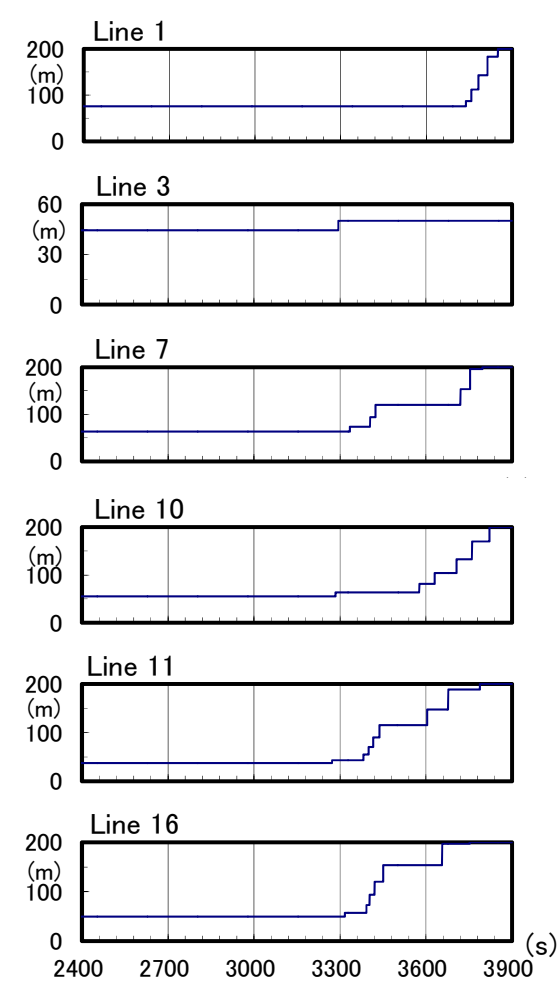

(b) Line length

Fig. 14 Numerical results of line tension and length during the tsunami

変位の時系列計算結果から算出した各防舷材の特性 曲線を示している。津波第 1 波が到達した際の時刻 $3244 \mathrm{~s}$ での栈橋変形量は約 $0.2 \mathrm{~m}$ である。ここに変形

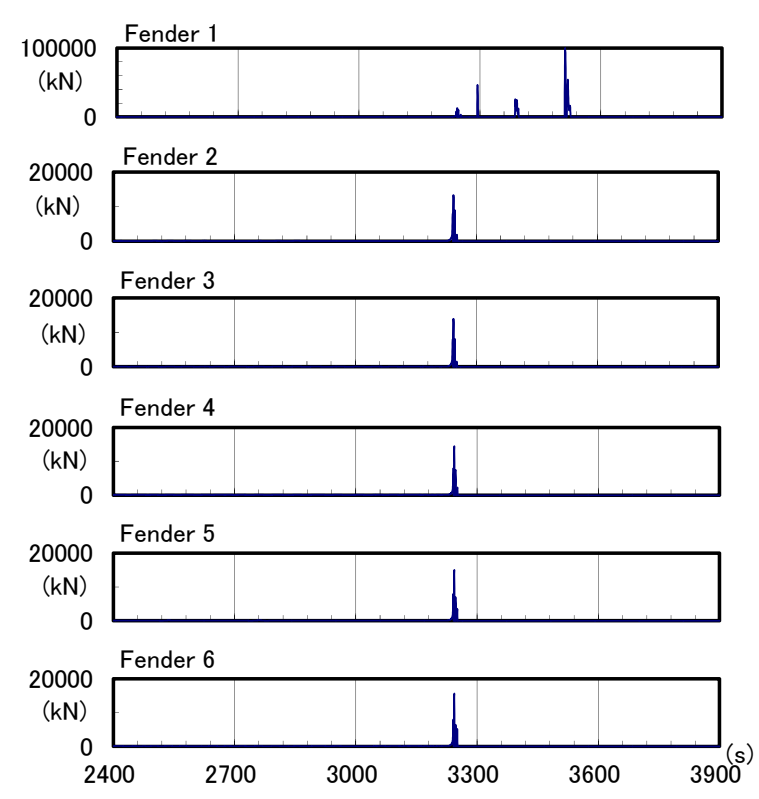

(a) at $2400-3900 \mathrm{~s}$
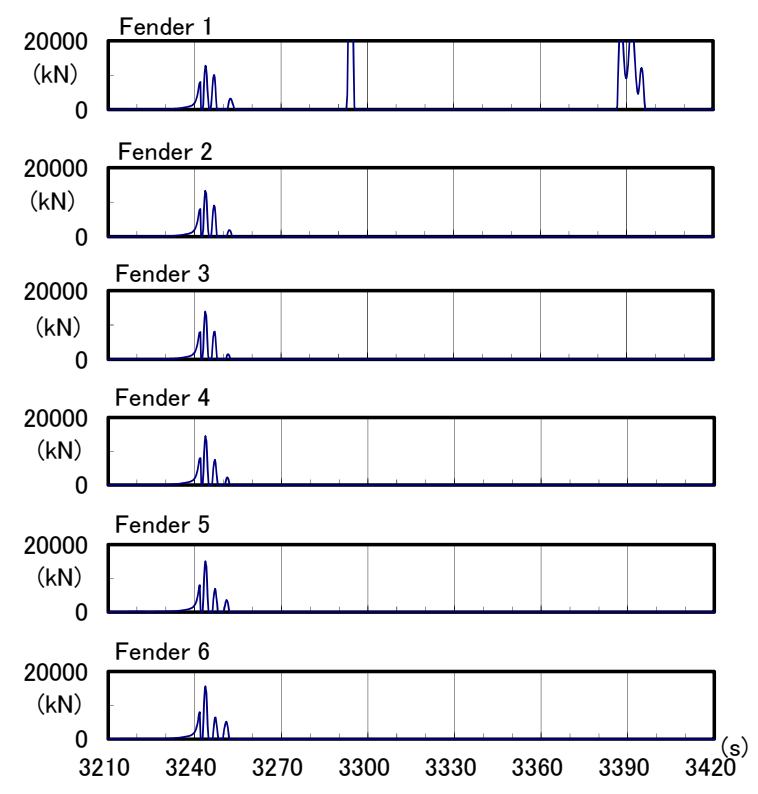

(b) at $3210-3420 \mathrm{~s}$

Fig. 15 Numerical results of fender reaction force during the tsunami

量 $1.81 \mathrm{~m}$ (圧縮率 $90.5 \%$ ) までは防舷材と栈橋を合わ せた直列バネ特性により船体には反力が与えられ、 圧縮率 $100 \%$ を超えた場合には栈橋のみのバネ特性 により反力が与えられることから、急激な反力が生 じていることがわかる。特に船首側の防舷材 F1 では、 時刻 15:44: 31 頃 (3511s) に 100, 000kN に及ぶ大きな 反力と栈橋への変形量 $1.358 \mathrm{~m}$ が生じている。これ は防舷材の破損、アンローダ先端部の引きちぎり、 さらには係留索巻き出しが進み本船が流出し始めた 際に生じた Yaw の大きな左舷回頭に起因している。 

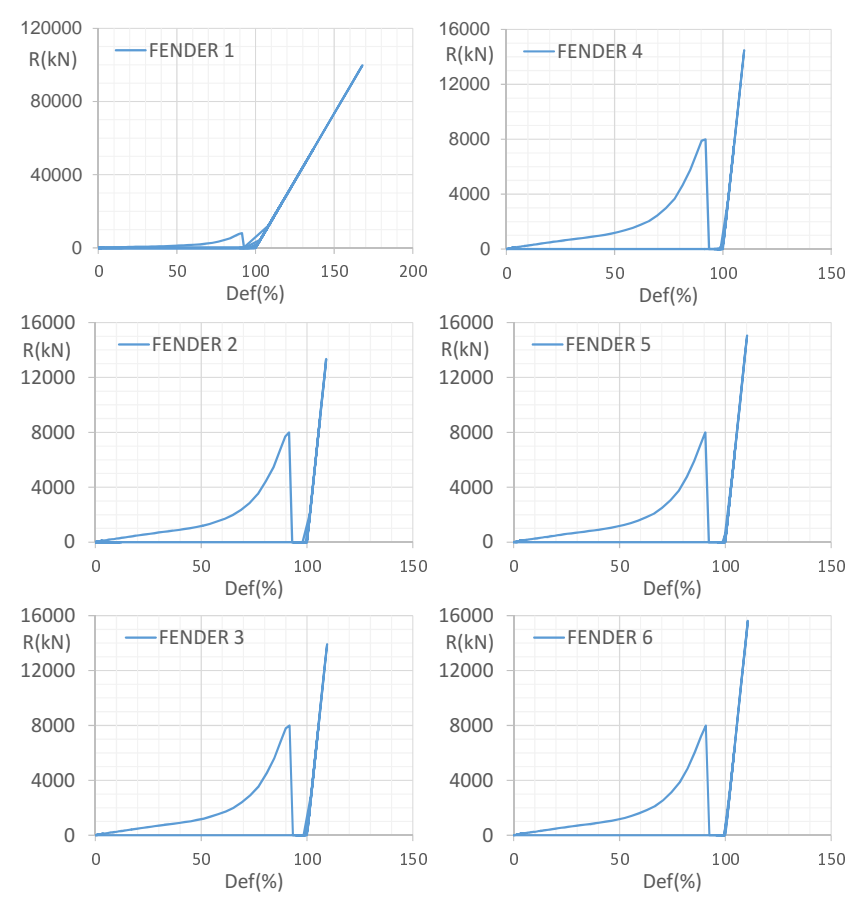

Fig. 16 Numerical results of fender performance during the tsunami

\section{5. 結語}

本研究では東北地方太平洋沖地震津波来襲時に 津波高さ $10 \mathrm{~m}$ 超の津波来襲に遭遇して係留・荷役施 設および本船に甚大な被害を受けた大型石炭船の挙 動につき、可能な限り入手できた被災状況を整理す ると共に、合わせて津波および船体動摇シミュレー ションを実施して被災当時の船体挙動や係留力の再 現を行い当該大型石炭船が遭遇した被災状況の定量 的な把握を試みた。得られた主な結論を要約すると 以下のようになる。

(1)東北地方太平洋沖地震発生 53 分後の 15 時 39 分 頃には津波が港口に到達し、押し波来襲から約 5 分で港内全域に $10 \mathrm{~m}$ 超の津波高さおよび港内中央 に $10 \mathrm{kt}$ を超える流速が生じ、また陸域にも越流 が広い範囲で来襲して、港湾のほぼ全域が津波高 さ $10 \mathrm{~m}$ 超となる津波状況であった可能性を明らか にした。

(2)当該大型石炭船栈橋周りでは、地震発生 54 分後 の 15 時 40 分に南東側の港口から押し波が到達す ると共に、南防波護岸・南防波堤からの越流が 15 時 42 分頃に陸側から来襲寸る複雑な流況になっ ていたことを明らかにした。

(3)地震津波来襲により甚大な被害を受けた当該大 型石炭船および荷役・係留施設の被災状況につき、
栈橋設置の防舫材破損や栈橋バネのモデル化、ホ ールド内に残されたアンローダ先端部による船 体拘束力のモデル化、また船体の着底効果のモデ ル化、さらには複雑な栈橋周りの流況での津波波 力のモデル化を行うことで、被災当時の船体動摇 量や係留力などを定量的に明らかにした。

本研究では、東北地方太平洋沖地震津波来襲時に $\mathrm{H}$ 港で津波高さ $10 \mathrm{~m}$ 超の津波来襲に遭遇して係留・ 荷役施設および本船に甚大な被害を受けた大型石炭 船の挙動につき定量的な把握を試みたが、AIS デー 夕などの船体実測挙動は入手できず当時の状況を知 る方からのヒアリング調査結果などに基づいている。 また防舷材の過圧縮時の特性や栈橋のバネ特性、ア ンローダ先端部による船体拘束力のモデル化、さら には津波高さ $10 \mathrm{~m}$ 超に加え越流も混在する流況での 船体に作用寸る津波波力には大胆な仮定・設定に基 づき行っている。結果として係留施設や荷役施設の 破損・損傷状況の再現は概ねできたが、モデル化に ついては課題が残されている。本件の上述のモデル 化改良をさらに進めると共に、引き続き東日本大震 災で被災した係留船舶の挙動分析や定量的解析を行 いたく考えている。

本研究が地震津波来襲時の船舶係留の安全性に ついての定量的な評価・把握および今後の対策・減 災への一助となれば幸いである。

\section{参考文献}

（1）榊原繁樹 - 阿部郁男 - 津金正典 - 久保雅義 : 東 北地方太平洋沖地震津波来襲時の係留 VLCC $の$ 挙動再現について, 日本航海学会論文集, 第 127 号, pp. 57-68, 2012.

（2）榊原繁樹・阿部郁男 - 津金正典 - 久保雅義 : 東 北地方太平洋沖地震津波来襲時のアフラマックス外准 係留避泊に関する一考察, 日本航海学会論文集, 第 129 号, pp. 19-30, 2013.

（3）（社）日本海難防止協会 : 大地震及び大津波来襲 時の航行安全対策調查報告書 一津波影響によ る船舶避難行動と被災状況等に係る基礎調査-, 2012. 3.

（4）斉藤知秀- 森 吉之 $\cdot$ 内海 博: 東日本大震災 による火力発電所土木構造物の被害と対策, 電 力土木，第 360 号，pp. 7-11， 2012.

（5）今村文彦・越村俊一 - 村嶋陽一 - 秋田善弘 - 新 谷勇樹: 東北地方太平洋沖地震を対象とした津 
波シミュレーションの実施, 東北大学モデル (version 1.1, version 1.2), http://www. tsunami. civil. tohoku. ac. jp/hoku sai3/J/events/tohoku_2011/mode1/dcrc_ver1. 1_111107.pdf 2011.11, 2012.4.

（6）阿部郁男・今村文彦：リアルタイム津波予測実 現に向けた計算方式の評価と改良, 土木学会地 震工学論文集, No. 27, pp. 319-325, 2003.

（7）榊原繁樹 - 阿部郁男 - 津金正典 -久保雅義：東 北地方太平洋沖地震津波による栈橋係留の超大 型原油タンカーの被災実態, 土木学会論文集 B2 (海岸工学)，Vol. 68, No. 2, pp. 816-820, 2012.

（8）元良誠三監修: 船体と海洋構造物の運動学, 成 山堂，第 128 号，pp. 97-101， 1982.

（9）榊原繁樹 - 阿部郁男 - 津金正典 -久保雅義 : 港 内係留船舶のかく坐による津波対策に関する基 礎的研究, 日本航海学会論文集, 第 128 号, pp. 251-260, 2013.

（10）日本港湾協会 : 港湾の施設の技術上の基準・同 解説, 2007. 